\title{
A Lacanian supplementation to love in L'Immanence des vérités
}

\author{
Park Youngjin ${ }^{1 凶}$
}

In L'Immanence des vérités, Alain Badiou rewrites the Platonic allegory of the cave. As the book's structure reveals, Badiou's central claim is that truths are absolute, for they are constituted by the dialectic between finitude and infinity, the consequence of which lies in the creation of the œuvre. Although love is often affected by individual difference, family, money, and social norms, philosophy calls for a rupture with these instances of finitude, awakening us to the truth that love is open to the possibility of infinity embodied by contingent encounter, amorous declaration, and the faithful construction of the Two. Badiou calls for subjectivization of this possibility in the form of the amorous œuvre, through and beyond the Lacanian impasse of the sexual non-relationship. This article supplements Badiouian love with Lacanian psychoanalysis by developing five points. First, the binary framework "Lacanian finitude vs Badiouian infinity" can be misleading. Second, Badiou himself regards the unconscious and the analytic discourse as inscribed by the dialectic between finitude and infinity. Third, Lacan allows us to recognize that the œuvre and the waste are not opposed, but rather supplementary to each other. Fourth, for both Lacan and Badiou, love constitutes the interlacing of the non-relationship and the Two. Fifth, the Badiouian amorous absolute must deal with the real of the absolute as the fusional One and thus, can be supplemented by the Lacanian problematic of the sexual relationship in its fantasmatic form of the One. Based on these points, this article elaborates such concepts as the amorous labor, the dialectic between œurre and waste, and the artisan of love.

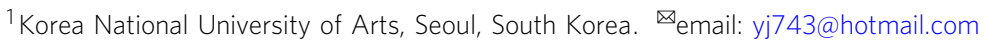




\section{Introduction: L'Immanence des vérités and Love}

n L'Immanence des vérités, Badiou rewrites Plato's allegory of the cave. He starts with an analysis and critique of finitude, moves onto an exploration of the kingdom of infinity, and concludes by elaborating on the theory of the ouvre, the finite form of truth that is open to infinity. The book's itinerary can thus be summed up as "finitude-infinity-œuvre." If Being and Event focused on the universality of truths (the generic multiplicity that is indiscernible to the knowledge of the situation) and Logics of Worlds supplements Being and Event by articulating the particularity of truths (the incorporation of the consequences of the inexistent in a specific world), L'Immanence des vérités clarifies the absoluteness of truths. Truths are absolute, in that the dialectic between finitude and infinity leads to the creation of the œuvre endowed with an index of absoluteness. It is possible to address love as truth in terms of this itinerary. The human animal's love is often constituted by the apparatuses of finitude, such as sexuality, capital, convention, identity, and death. Philosophy, however, calls for a rupture with finitude and encourages us to turn to infinity. More specifically, philosophy affirms the contingent encounter outside of the pre-existing law, the declaration accompanying existential commitment, the rigorous fidelity coordinating individual difference, and the metaphysical happiness originating from the amorous process itself. To support this affirmation, Badiou appropriates the mathematical theory of large cardinals to show the immanent possibility of infinity against the power of finitude. A key point here is the distinction between the constructible (finitude) and the generic (infinity). If the former refers to what is definable by the dominant language, the latter refers to what is elusive to and subtracted from the defining power of the dominant language. Transposing this distinction onto the domain of love, we can state that if family, ideology, social norms constitute finitude (l'amour à la Gödel), evental encounter, amorous declaration, and the construction of the Two constitute infinity (l'amour à la Cohen) (Badiou, 2018a, p. 264). Although it is easy to be affected by the constituents of finitude, it is always possible to support and subjectivize the amorous infinity. However, there is a point of the impossible, regarding which the amorous infinity should be moderate and temperate. It is the mortal passion of becoming the One, which constitutes a deviant approach to the amorous absoluteness. Love can persist only insofar as it does not yield to the temptation of the fusional One. After exploring the amorous infinity and its limit point, one descends to the territory of finitude. Here, one is no longer faced with love as the waste (déchet) that is passively stuck onto finitude, but with love as the œuvre (œuvre) that is actively interlocked with infinity, despite its finite form, and dynamically expandable based on its subjective elaboration. For Badiou, who appropriates and transforms Lacan, the amorous œuvre consists of faithfully constructing the Two, while coming to terms with the impasse of the sexual non-relationship. More specifically, Badiou appropriates the Lacanian thesis that love makes up for the sexual non-relationship, eventually introducing his own idea of the Two that creates the amorous œuvre. "We will maintain, with Lacan, that at the very point of the vanishing relation between the sexes love can come to make relation ... love will make the truth of the sexual non-relationship by introducing into it what it lacks: the symbolic power of the Two" (Badiou, 2018a, p. 612). The amorous œuvre based on the power of the Two shows that love is not merely universal (transmissible beyond worldly boundaries) or singular (connected to a specific world), but absolute; this is to say that it creates the amorous Two like a complete cardinal, which means that the amorous world subjectively constructed by lovers is as powerful as or more powerful than the existing objective world. Here, love reveals itself not as a transient feeling, but as an absolute index, inscribing the figure of humanity within the trans-human truth.

\section{From critique to supplementation}

Certainly, this vision of love often provokes a backlash. Let us introduce one line of critique. Badiou presents the principle of maximality as a core axiom of the approach to infinity (Badiou, 2014 , p. 11). This principle stipulates that any intelligible entity exists, insofar as its existence can be inferred without any contradiction from the axioms concerning the entity in question. Here, some may argue that Badiouian love is derived from the philosophico-mathematical thesis that presupposes equivalence between being and thinking. For such an opponent, love as truth is nothing but a construct of thought, belonging to a theoretical fiction suturing love to mathematics. Other detractors, however, may argue that love as truth is a consequence of a decision suturing love to politics. For instance, Badiou notes that there is a political implication of the axiom of choice, in that this axiom allows for a representation beyond the pre-established law (Badiou, 2014, p. 20). It is akin to an anonymous participant in a revolutionary movement suddenly offering an improvised speech. Although parliamentary democratic regimes emphasize reliable entitlement, the axiom of choice presents illegal and supra-legal entitlement. Interestingly, the axiom of choice also fits into Badiou's critique of online dating systems and family systems, both of which demand that love be based on a calculable property and a predetermined guarantee. For this opponent, however, Badiou is transforming the communist political subject into the amorous subject, radically emancipated from the contemporary capitalist, technocratic, familial regime. In sum, these two critiques regard Badiouian love as a consequence of applying an over-arching philosophical truth to particular mathematical axioms and political decisions.

These are external critiques of Badiou's system, but there can be an internal critique as well. According to such a critique, Badiou treats finitude too lightly. After all, to use the Spinozan terms, finite modes exist alongside infinite modes. To use the set theoretical terms, there are not only infinite sets, but also finite sets; Badiou, on this view, never takes finite modes and finite sets seriously. Badiou's likely retort is that his vision is hardly lopsided toward infinity and that the ouvre actually embodies a dialectical relation between infinity and finitude. In fact, Badiou points out that the total rupture with finitude amounts to an ultra-leftist chimera (Badiou, 2018a, p. 266). The œuvre does not require a global separation from finitude, but rather a local rupture with finitude. This viewpoint is already present in the Theory of the Subject where Badiou notes that while an exclusive focus on force (e.g., Deleuze's chaos) belongs to the ultra-leftist deviation, an exclusive focus on place (e.g., Lévi-Strauss's structure) belongs to the ultra-rightist deviation (Badiou, 2009b, p. 207). This opponent nevertheless insists that Badiou's approach may be conceived of as infinity-centrism, calling our attention to the facticity of finitude with which one should cope, and not the ideology of finitude by which one is enslaved. Given that the œuvre of love, "apart from the familial state, seem doomed to sporadic moments of ecstasy" (Badiou, 2018a, p. 560), the opponent may also affirm, like Blanchot, that ecstasy as an instance of disaster is "not absolute but disorients the absolute" (Vinciguerra, 2014, p. 164). Love constitutes our existential drama not only with happiness but with disaster, and disaster does not simply subordinate us to nihilism, but rather disorients the absolute. While love evokes the possibility of participating in infinity despite our finite existence, love also testifies to the impossibility of ignoring finitude. In 
L'Immanence des vérités, Badiou argues that, while the size of the world amounts to an inaccessible cardinal, the size of the amorous œuvre amounts to a complete cardinal that is superior to an inaccessible cardinal and subsumes it from above. According to this opponent, however, we cannot state that love overwhelmed by the worldly logic, which fails to create a complete cardinal, is not genuine love. The opponent would state that love as truth addresses only a partial and narrow spectrum of love. In sum, this critique asserts that Badiou too easily dismisses the significance of amorous finitude.

For our part, leaving aside the conditions in which these critiques are justifiable, let us recall Badiou's response to Peter Hallward, who criticized Badiou's presentation of abstract thinking that reduces empirical multiplicities to formal multiplicities (Badiou, 2004, p. 232). One may consider a similar kind of critique with regard to love in L'Immanence des vérités: "In what way does love have anything to do with the theory of large cardinal?" Here, we may expect Badiou to repeat his answer to Hallward: "I believe it is more important to axiomatize my intentions (sic); I am perfectly aware of the paradoxical violence of the statements I uphold" (Badiou, 2004, p. 237). Here, it is notable that, at the end of this response is a full presentation of the core thesis of L'Immanence des vérités. As Plato's Cave suggests, philosophy operates as an awakening from ordinary and mundane life, and it is only through awakening that we live as Immortals (Aristotle) or, consider the absolute with us all along (Hegel). Moreover, an awakening is possible only by emancipating ourselves from "an anthropology of finitude" (Badiou, 2004, p. 237). Badiou is absolutely convinced that the duty of philosophy is to break with the dogma of finitude and awaken us from the slumber of finitude. In this respect, no external critique can dampen the philosopher's determination to uphold his paradoxically violent theses, and no internal critique can discourage the philosopher's courage to fight against the mastery of finitude. This article argues that a more reasonable engagement with Badiou consists neither of external nor internal critiques, but rather of a subtle supplementation to Badiou. To produce this supplementation, this article uses the same material used by Badiou to present love as truth, that is, Lacanian psychoanalysis. ${ }^{1}$

Lacanian finitude vs Badiouian infinity?. Let us construct this supplementation in five points. The first point concerns finitude and infinity. In Conditions, Badiou points out the essential finitude of the Lacanian subject, for Lacan restricts the concept of infinity to inaccessibility, as if the number 2 is inaccessible through the conjunction of the preceding numbers of 0 and 1 (Badiou, 2004, p. 225). Here, a Lacanian may argue that the Lacanian feminine subject is not essentially finite. While the phallic function, which affects all speaking beings, corresponds to finitude, feminine jouissance, which goes beyond the phallus, corresponds to infinity. However, Badiou identifies an equivalence between finitude and the sexual non-relationship, even between finitude and feminine jouissance, based on Lacan's following remark: "Its finitude [the finitude of the drives] is related to the impossibility which is demonstrated in a genuine questioning of the sexual relation as such" (Badiou, 2004, p. 226). Although it is unclear how the equivalence between finitude and feminine jouissance can be derived from this passage, the connection between finitude and the impossibility of the sexual nonrelationship is made clearly here. But things change, as Lacan develops the feminine "not-all" in Seminar XX. A woman is notall because of "a jouissance that, with respect to everything that can be used in the function of $\Phi x$, is in the realm of the infinite" (Lacan, 1998, p. 103). Here, the infinity of feminine jouissance, which goes beyond the phallic finitude or the finitude of the drives, is affirmed. For Badiou, however, this is unsatisfactory, for the infinity of feminine jouissance is, at best, the infinity of inaccessibility. Feminine infinity is not positively infinite. It is negatively infinite in the form of the unrepresentable experience, in the same sense that we do not know how God transcends human imperfection, even as we do know that God transcends human imperfection. Meanwhile, Lacan, in Seminar XVI, states that the hysteric poses the infinite point of jouissance as absolute (Lacan, 2006a, 2006b, p. 335). However, the hysterical infinity comes closer to finitude, for the hysteric aims not at satisfaction, but at dissatisfaction. Her jouissance is constituted by the absence of jouissance. The hysterical infinity is a negative infinity. Because of this negative aspect of the Lacanian infinity, Badiou would confirm that the Lacanian infinity is pre-Cantorian. Meanwhile, Lacan, in Seminar XXI, connects the not-all with the Cantorian Aleph-naught (Lacan, 1973, the lesson of 19 February 1974). However, whether Lacan is pre-Cantorian or Cantorian, AlephNought (e.g., the cardinality of the set of the natural numbers) is not sufficiently infinite for Badiou. Badiou, in L'Immanence des vérités, describes the kingdom of infinity as a hierarchical structure in which there are four types of infinity: infinity as inaccessibility, infinity as resistance to division, infinity as immanence of large parts, and infinity as proximity to the absolute. These correspond roughly to inaccessible cardinal, compact cardinal, Ramsey cardinal, and complete cardinal. All of these are absent from Lacan's engagement with infinity. Moreover, Badiou points out a correlation between Lacan's insufficient engagement with infinity, his political skepticism, and his rational pessimism.

\begin{abstract}
"It is moreover a regrettable error of Lacan in Seminar... or Worse to let people believe that the infinities higher than $\omega$ are only fictions. By doing so, he paid in pure theory the price of his political skepticism, and more generally of rational pessimism which is the ordinary attitude of psychoanalysts, who are quotidianly confronted with the subjects' banal miseries instructed by death drive" (Badiou, 2018a, p. 323).
\end{abstract}

It is indeed true that the analytic work attempts to transform neurotic miseries into common unhappiness through the activation of the unconscious. However, this article argues that the schema "Lacanian finitude (or inaccessible infinity) vs. Badiouian infinity" can be misleading, especially when we consider Badiou's discussion of the unconscious and the analytic discourse in terms of finitude and infinity. ${ }^{2}$

The unconscious and analytic work. In L'Immanence des vérités, Badiou assumes an ambivalent and contradictory perspective on the unconscious. On the one hand, he argues that the unconscious is subject to finitude. Consider the following remark: "The fundamental ontological hypothesis of any oppressive system, whatever it is (including, for example, the unconscious of an individual), asserts the unlimited sovereignty of finitude, which amounts to affirming that all that is, all multiplicity, is constructible" (Badiou, 2018a, p. 268). On the other hand, he supports the infinity of the unconscious when he suggests that one immanentize the Cartesian idea of God. Twisting the Lacanian formula a bit, Badiou states that "God is the unconscious itself" (Badiou, 2018a, p. 188). That is to say, the conscious representation does not know the divine infinity, and yet, the unconscious knows it very well. God as the unconscious is "the latent, immanent infinite resource, of which we have only signs at the conscious level" (Badiou, 2018a, p. 188). Moreover, Badiou maps his notion of the event onto the unconscious inscription. The event as an aleatory interruption of necessary norms is "always 
subjectively inscribed, first, in the unconscious" (Badiou, 2018a, p. 188), and the operation of the subject of truth lies in elaborating the unknown consequences of this inscription. Badiou also accepts that, if repression corresponds to the apparatus of finitude in psychoanalysis, the analytic work lies in stripping away repression, through the activation of the unconscious as the immanent infinity. In this respect, the unconscious is not merely finitude-based, but actually touches on infinity. In fact, Badiou's ambivalent and contradictory remarks on the unconscious hardly owe to coincidence or error, insofar as the unconscious is constituted by ambivalence and contradiction as such. On the one hand, if an analysand's unconscious does not oppressively push him/her to the deadlock of finitude, we cannot ever make sense of why the analysand uses the analytic work to explore an outside chance. On the other hand, however, if the unconscious does not contain an immanent infinity, we cannot ever make sense of how the analytic work can lead to the practical effect of subjective change. Here, let us recall Lacan's formulation: "Desire merely subjugates what analysis subjectivizes" (Lacan, 2006b, p. 520). Psychoanalysis aims to emancipate the subject whose pathological symptom is reinforced by the pre-existing desire as the restrictive law.

In a 2018 conference after the publication of L'Immanence des vérités, Badiou actually adopts a similar attitude towards psychoanalysis (Badiou, 2018b, n. p.). He first states that, for Lacan, infinity is a figure of feminine desire, and that this feminine infinity belongs to a classical discourse originating from Greek tragedy. Then, he states that the relation between finitude and infinity is analogous to the relation between the symptom and the unconscious. The analytic work mobilizes the unconscious as infinity to destabilize the symptom as finitude. Insofar as the unconscious is the reservoir of the subjective infinity, the analytic work moves from the symptom as the finite unconscious formation to the underlying structure causing the symptom, supporting the plasticity of the unconscious. During this process, analysis encounters the unrepresentable point of loss and void, around which the analysand's drive circulates, which Lacan calls the object a. Through this encounter, the subject experiences his/ her constitutive division and explores an occasion for a new subjectivization.

One of the key operators in the analytic work is repetition, insofar as the analytic material is the unknown knowledge (the unconscious) that the subject unwittingly repeats. However, the analytic work ultimately straddles a line between repetition and the unrepeatable: the analysand is not only encouraged to create a new signifier by working through the repeated signifiers, but also to invent a way of living with the symptom by working through the repeated symptom. In this regard, the analytic work is inscribed by the dialectic between repetition and the unrepeatable. Interestingly, in L'Immanence des vérités, Badiou regards repetition as one of the operators of finitude (the others are identity, evil, necessity/God, and death). For Badiou, Koltès' play shows the eternal repetition of buying and selling in the modern world, which produces miserably isolated individuals. However, Badiou also observes that Kierkegaard affirmed that his love for Regine belonged to the order of the unrepeatable. The logic of the analytic work is precisely constituted by the interplay of repetition and the repeatable. On the one hand, the analytic work deals with the impasse of repetition that is stuck onto finitude. On the other, the analytic work engages with the power of the unrepeatable that is open to infinity. If the analytic works provokes the structural transformation of the analysand, it is because, to use Badiou's expression, "it is within the repetition of what is unrepeatable, of what has taken place only once (Badiou, 2018a, p. 149)".

In this regard, rejecting the misplaced framework of "Lacanian finitude vs. Badiouian infinity," we can draw a more nuanced conclusion. Despite their theoretical and practical differences, Lacan and Badiou agree on the following point: The unconscious is an interlacing of finitude and infinity, and the analytic work aims at the unrepeatable subjectivization based on the infinity of the unconscious beyond the repeated finitude of the symptom.

Between Euvre and waste. This leads us to the third point. How then is the analytic "work" similar to and different from the Badiouian "œuvre"? This requires attention, for one possible translation of "œuvre" is "work." Let us first consider how Lacan addresses work (travail) and waste (déchet). For Lacan, work is a product of the master discourse. Work is something that the master as the agent commands the slave as the other to accomplish. After all, is it not a master who declares "time to work"? Work is also a product of the capitalist discourse focusing on social utility and calculable performance. Thus, the subject is haunted by the following superegoic voice: "Only those who work are allowed to enjoy," or "work hard, then you will be able to enjoy someday." However, work does not belong exclusively to the master discourse. Work is concerned with the analytic discourse as well. In Seminar XVI, Lacan states that psychoanalytic experience allows us to introduce the analogy between truth and work. "In the analytic discourse, the work of the truth is rather obvious, because it is painful (Lacan, 2006a, pp. 199-200)." The analytic discourse is not only about the articulated knowledge of the unconscious that the subject does not know yet repeats, but about the not-all sayable truth, namely, gaps in knowledge, such as sexuality, trauma, death, and jouissance.

Moving onto waste, Lacanian waste is very different from Badiouian waste. In Seminar XV, Lacan states that waste is compatible with the analytic act (Lacan, 1967, the lesson of 6 December 1967). This is because the analyst serves as the abject object that captures the analysand's uninterpretable jouissance, thereby mirroring the subjective real of the analysand. The waste implies that the analyst is not really an analyst, but rather a semblance, namely, an instrument supporting the analysand's singular subjectivization. Certainly, at the beginning of analysis, the analyst is positioned at the point of idealization (I) or the subject-supposed to know. As analysis progresses, however, the analyst's status falls into the waste-object a, whose functional necessity consists only of encouraging the analysand to face his/ her subjective real and find a way to live with his/her opaque jouissance through a proper symbolization. Here, let us map the idea of civilization as sewer (égout) in Seminar XXI onto obsessional neurosis. (Lacan, 1973, the lesson of 9 April 1974). The obsessional neurotic loves consciously, but hates unconsciously. That is to say, he is too civilized and is therefore obliged to love his neighbor and repress hate. Such ambivalence generates a variety of ritual symptoms for the obsessional, such as washing, checking, counting, and ruminating. He is the incarnation of discontent in civilization, with his symptom being the stupidity of truth or the truth of stupidity. As Denise Lachaud writes, "Who better than the obsessional could state loudly what every speaking being repressed: in the beginning was hatred?" (Lachaud, 1995, p. 320) The analyst as the waste helps the obsessional work through his unconscious hatred as the sewer of civilization. Incidentally, the work with the obsessional proves that love cannot be devoid of hatred, insofar as speaking being located within civilization is concerned. Here, let us refer to Lacan's remark in Seminar XX, frequently quoted by Badiou. "It is love that approaches being as such in the encounter" (Lacan, 1998, p. 145). But Lacan immediately adds that, in love, at stake are beings who do not meet each other, beings who are affected by the sexual nonrelationship; Lacan finally concludes that love gives way to hatred. Love as the approach to being and hatred as the missed encounter 
with being are interlocked. Therefore, the axiom that love is hainamoration (the nexus of hate and love) constitutes the first truth of psychoanalysis (Lacan, 1974, the lesson of 15 April 1975). ${ }^{3}$

Finally, let us refer to the text "The pleasure and the fundamental rule (Le plaisir et la règle fondamentale)" in which Lacan relates the analytic work to the work of art (œuvre d'art) (Lacan, 1978). Lacan first specifies that the function of the pleasure principle lies in regulating the stimulus as minimally as possible. In fact, insofar as the pleasure principle is interlocked with the reality principle, it is no more than a conservative apparatus that distinguishes between the normal and the abnormal, the average and the exceptional. However, the pleasure principle is ultimately dislocated and disoriented by a paradoxical pleasure. In other words, it falls into the trap of jouissance. Furthermore, psychoanalysis addresses the symptom as the particular mode of jouissance, identifying it with a particularity. In some fortunate cases that successfully disentangle the knots of symptom-particularity, analysis allows the analysand to reach his/ her singularity, name, and destiny. Lacan compares this singularity to a work of art. Here, the analytic work leads the analysand to reconcile with his/her singular destiny after working through his/her particular symptoms. However, Lacan concludes that this is not the analyst's intention. "It [our intention] is not at all to lead someone to make a name for him/herself or to make a work of art. It is something which consists in inciting him to go through the good hole of what is offered to him as singular" (Lacan, 1978, p. 24). Sometimes, analysis has a chance of turning the analysand's singularity into a work of art. But the fundamental goal is to incite him/her to go through the hole of such a work of art, no matter how painstakingly the work has been created. This is also clinically relevant. As Darian Leader notes, the melancholic clinic lies in enabling the analysand to "find words to say how words fail," insofar as the melancholic suffers from the radical separation between words and things due to irremediable loss (Leader, 2008, p, 191). What is at stake is to create something through the unrepresentable hole and preserve the hole through the creation.

Having considered all of this, the Lacanian work-waste-work of art has an interesting impact on the conceptual configuration of the Badiouian ouvre-waste. For Lacan, the work can signify both the product of the master's commandment and the analytic work of the truth, and waste has a clinically significant value. Moreover, although the work of art is regarded as a singular destiny beyond particular symptoms, the core of the analytic work consists of passing through the hole of the work of art. For Badiou, while the œuvre is the finite form of the active effect of infinity, the waste is the finite remainder of the passive consequence of infinity. But the Lacanian triad "work-waste-work of art" is not simply incomplete or imperfect, in light of the Badiouian œuvre. Still less do they belong to Badiouian waste. Rather, the Lacanian triad blurs the philosophical distinction between œuvre and waste, although for Badiou this distinction is as absolute as the Platonic distinction between truth and opinion. Lacan points to the ambivalence of work, clarifies the positive and indispensable value that waste contains, and articulates the importance of the hole of the work. Put simply, the Lacanian triad suggests the possibility of the interlacing of the œuvre and the waste. In fact, in L'Immanence des vérités, Badiou writes,

\footnotetext{
"Making œuvre with regard to finitude, ontological here, political for Marx, exposes us to the stirring-up of so much waste that there is always a risk of interrupting the œuvre and being satisfied with a few possible acts. But acts are
}

nothing if they are not also œuvre. We must therefore continue to clear away in order to make, and this is why any œuvre takes with it, like a building site does, the obscure and indistinguishable pile of waste that it must have stirred up" (Badiou, 2018a, p. 462).

The categorical distinction between œuvre and waste can be mitigated. After all, creating the œuvre and clearing the waste are coexistent. To make a satisfactory œuvre, one should process the waste skillfully. One may note that, sometimes, the pile of waste turns into the œuvre through artistic elaboration. Refer to the project Plastikophobia, made by Benjamin Von Wong, Joshua Goh, Laura François, and hundreds of volunteers. Constructing a large-scale installation piece made of 18,000 plastic cups collected from restaurants in Singapore, the project evokes the extent to which disposable items affect the environment. Although the title of the project contains the pathological symptom, its visible effect is so powerful that it offers the following politico-environmental message to the contemporary world: It is time to promote awareness of the truth that humanity is not the master of the globe. Let us also note that, as this project transforms piles of plastic cups into a crystal cave, it fits well into Badiou's critical message to the contemporary art world, which is that art is not a blatant exposure of death, violence, sex, and body, but rather a creation of a new form. Therefore, the project realizes a supplementary relationship between œuvre and waste in artistic truth procedure, dismantling our conventional ideas of the distinction between œuvre and waste.

Sexual non-relationship and Two. How then does the supplementary relationship between œuvre and waste actually appear in the domain of love? This questions leads us to the fourth point about the Lacanian sexual non-relationship and the Badiouian Two. For Badiou, love that does not transform the sexual or work through the impasse of the sexual non-relationship remains a waste. Only love that comes to terms with the sexual impasse and constructs the faithful Two can become an œuvre. More specifically, Badiou brings up two kinds of elements in love. On the one hand, at the stage of contingent encounter, love is affected by the object-cause of desire $\mu$, which reduces the beloved's total being to a partial object. While this object clearly explains the evental aspect of love, it is not sufficient for Badiouian love. Badiou argues for "a concept of love that is less miraculous and more hard work, namely, a construction of eternity within time, of the experience of the Two, point by point" (Badiou, 2012, p. $80)$. When the charm of $\mu$ is no longer operative, what remains is mutual misunderstanding as an instance of the sexual nonrelationship. Badiou therefore brings up another element $t$, which is gradually constructed during the amorous process and subtracted from the sexual positions of both Man and Woman. This implies that lovers, in their engagement with $t$, appeal to neither Man nor Woman, but to Humanity, which can be summoned from the perspective of the Two. Love is an index of the absolute, because it attests to Humanity as touched upon by the Two. In sum, if $\mu$ is on the side of the sexual impasse, despite its evental power, then $t$ illustrates the properly amorous aspect, which is the construction of the Two beyond the sexual.

Interestingly, we can observe that Lacan, in his own way, considers both the non-relationship and the Two in different places. On the one hand, Lacan sticks to his axiom that there is no such thing as the sexual relationship. Even the analytic discourse cannot overcome the impasse of the sexual non-relationship. Rather, the analytic discourse prefers to support and preserve the impasse. "Not that one could ever expect from it [the new discourse that is analysis] the relation that I'm referring to, namely that it is the absence [of the relation] that gives the 
speaker access to the real" (Lacan, 2001, p. 506). While the absence of the sexual relationship amounts to the real of the speaking being, one cannot expect that the analytic discourse authorizes or guarantees the sexual relationship. But Lacan also states in "The Third" that the singularity of the analytic discourse consists of making a bond of two. "Socially speaking, psychoanalysis has a consistency different from that of other discourses: it is a bond of two [un lien à deux]. It is in this respect that it occupies the place of the lack of the sexual relation" (Lacan, 2019, p. 87). Therefore, although Lacan does not authorize the relation [rapport] of two, he affirms the bond [lien] of two. And this bond, between the analyst and the analysand, does not amount to an overcoming of the sexual non-relationship. Rather, the bond of two and the non-relationship are superimposed. To use the Badiouian term, the bond of two arrives as an event in a supernumerary and supplementary way, where the sexual relationship is lacking. Moreover, just as the Badiouian scene of the Two does not pre-exist, but is constructed through the gradual exploration of properly amorous and a-sexual fragments, the Lacanian bond of two does not pre-exist, but is slowly established by the enduring symbolization of the subjective real. In this respect, to state that Lacan exclusively focuses on the real of the non-relationship, while Badiou exclusively focuses on the truth of the two is not nuanced enough. Rather, both Lacan and Badiou, albeit in different terms, recognize the troublesome situation that love confronts with the sexual impasse, and both point out the necessity of devising a consistent endeavor to find a way in that troublesome situation, instead of being discouraged and frustrated by it. To state that Badiou is easily sublating the sexual impasse though the amorous truth is as much a simplification as stating that Lacan is pessimistically stuck in the sexual impasse due to his skepticism of the possibility of the advent of the Two. Rather, it is important to note that the Badiouian amorous process as limping march implies that, without the impact of the non-relationship, love would never actually be limping and that the Lacanian consistency of the analytic discourse lies in the formation of the bond of two against the backdrop of the non-relationship. In sum, love constitutes an interlacing of the non-relationship and the Two. ${ }^{4}$

The absolute with its real. Finally, let us address the problem of the absolute in Badiou and how the Badiouian absolute can be supplemented by the Lacanian problematic. In L'Immanence des vérités, Badiou defines the absolute substance $\mathrm{V}$ as the place in which all set-theoretically multiple-beings can be thought. What is notable is the ambivalence of $\mathrm{V}$. On the one hand, $\mathrm{V}$ is open because it has a hierarchical structure that begins with the empty set and moves interminably upward to the complete cardinal and beyond. For Badiou, love can be evoked as both the empty set (the multiple of nothing as the indeterminate name) and the infinite multiplicities of large cardinals. "The power of the multiple and its empty 'heart' can also be summoned through ... the systematic play, carried to infinity, of pure difference" (Badiou, 2004, p. 234). Insofar as every multiplicity, including the empty set, can be summoned through love, love is pervasively embedded within the ever-ascending movement from the empty set to the complete cardinal and above. However, as Kunen's theorem proves, there is a limit to the ascending movement. In our approach to the absolute, an interminably open-ended succession is impossible, and this constitutes "the real of the absolute" (Badiou, 2018a, p. 681). $\mathrm{V}$ contains its own immanent impossibility. Therefore, $\mathrm{V}$ is not an ultimate form of infinity but a region that is both open and closed, a region that contains its real as the impossibility of endless openness. In this region, there is no such thing as the ultimate witness of the absolute. "There are absolute truths in a strict sense, but there is no truth of the absolute" (Badiou, 2018a, p. 499). However, one may be tempted to define the truth of the absolute and to possess the ultimate cardinal that entertains a privileged relationship with the absolute. In technical terms, this occurs when one engages in an elementary embedding (plongement élémentaire) of $\mathrm{V}$ into $\mathrm{V}$. In philosophical terms, one makes such a mistake by appealing to the internal movement of the substance, rather than dialectically touching the substance through the mediation of the attribute. In love, this temptation emerges as the desire to realize the One.

The ecstatic fusional love of romanticism ... is nothing but the desire to no longer have to deal with the gap, the difference, the separation between the absolute referent and the place of absolutization of singular truths. It is an immense hope to find ... an ultimate infinity as testimony of a truth without withdrawal or defect. The ambition, basically, to be in $\mathrm{V}$, the one that goes from V to V (Badiou, 2018a, p. 481).

Note that the absolute referent itself and the place of absolutization of truths are distinct. Truths can and must be absolutized, not by means of the substance $\mathrm{V}$, but by the attribute $\mathrm{M}$ as the internal model of $\mathrm{V}$. The gap between $\mathrm{V}$ and $\mathrm{M}$ must be maintained rigorously. For Badiou, the annihilation of this gap is compared to fusional love. In love, there is a constant risk of reducing the painstaking and procedural Two to the ravishing and substantial One. But love can survive and persist only when it continues to struggle with the gap between the One and the ever-precarious Two, rather than leaning toward the One, which ultimately leads to the self-destruction of love. Just as absolute power corrupts absolutely, fusional love perishes absolutely.

What is crucial for our discussion is the risky relationship that Badiouian love entertains with the One. Certainly, love as the Two is "not glued to the One," but at the same time, it is "not detached from the One" (Badiou, 2018a, p. 623). Love is a limping march, because it has to deal with the oscillation between the power of the One and the labor of the Two. In terms of the region of the absolute, mapping the labor of the Two onto the ascending movement in the kingdom of infinity is not the end of story. One also has to face the real of the absolute and stay alert to the overwhelming temptation to become the One.

Without a doubt, Lacan explores the problem of the One in relation to love and sexual relationship more closely than anyone else. We could state that Lacanian clinic is indispensable for Badiou, insofar as the temptation to be the One amounts to the real of the absolute. Notably, Badiou himself provides an analysis of the Lacanian One in his seminar on Lacanian antiphilosophy (Badiou, 2018c, pp. 52-65). For Badiou, there are two types of the One in Lacan. If "the One is" is supported by the metaphysical being, "there's some One" is supported by the analytic dis-being (désêtre). If the former subjugates the real through semblance, the latter does not do so. Noting that the question of the One and the question of love are closely interrelated for Lacan, Badiou also introduces Lacan's remark that a man who occupies the position of the One (mascul-One), yearns for a woman as the Other. Later, based on Lacan's thesis that love is at the heart of the philosopher's discourse, Badiou observes that love of truth in philosophy is love of power, whereas love of truth in Lacan is love of impotence. While all these observations form a crucial analysis of Lacanian antiphilosophy, such an analysis does not fit into our problematic of how to supplement the Badiouian absolute through Lacan. For that, we need to turn to the Lacanian sexual relationship in its fantasmatic One.

In Seminar XX, Lacan makes a distinction between the One of the sexual relationship and the One of set-theoretical difference 
or signifier (Lacan, 1998, pp. 7-47). If the former is related to fusional and natural love, the latter is related to a disparate and non-naturalized unit. While Lacan's underlying motivation seems to deconstruct the former's imaginary mirage through the latter's formalistic rigor, he also ironically accepts the fantasmatic reality of love. "Everyone knows, of course, that two have never become but one, but nevertheless 'we are but one.' The idea of love begins with that" (Lacan, 1998, p. 47). Thus, the One of the sexual relationship lays foundation for fusional love. Here, we should note that the consequence of fusional love is no longer imaginary and unifying but real and fragmentary, leading to devastating effects. Let us refer to Nagisa Oshima's film In the Realm of the Senses, where the woman cuts off the penis of her beloved in pursuit of her radical eroticism to fully become the One. In Seminar XXIII, Lacan remarks that the film is concerned with the woman's fantasy of symbolic phallus (Lacan, 2017, p. 107). Thus, the matheme of this film is not $S(A)$ where there is no Other that responds as a sexual partner, but $\Phi$ where there is the "Loving Other (l'Autre de l'Amour)" beyond her physical partner (Lacan, 2006b, p. 583). This is also why Lacan states that her fantasy is not just about killing the man, who is not her true partner. While her partner is an imaginary other, her true partner is the Loving Other. Moreover, "as for what the woman fantasizes, ... it is something that either way, impedes the encounter" (Lacan, 2017, p. 108). She does not need a contingent encounter with a man, because all she needs to do is to appeal to the Loving Other who is always already there. For Lacan in Seminar XX, love necessitates a contingent encounter, because only an encounter allows the sexual non-relationship_—which remains structurally unwritten_- to be written, albeit only momentarily (Lacan, 1998, p. 145). But all this is absent for the woman in the film. She kills her partner as a way of reaching the Other and attaining the One with the Other. Her fantasy of $\Phi$ allows her to enact the sexual relationship in a fantasmatic and destructive form. In Badiouian terms, we can state that this film is a clear example of executing the temptation to be the One or bumping into the real of the amorous absolute.

To conclude, let us note that Badiou regards $\mathrm{V}$ as both the abbreviation of "Truths (Vérités)" and the abbreviation of "Vacuum (Vacuum)" (Badiou, 2018a, p. 40). While one needs only Badiou when one limits oneself to $\mathrm{V}$ as Truths, one needs Lacan to recognize $\mathrm{V}$ as Vacuum. Philosophically, it is imperative to stay true to love as an absolute Truth. However, one is also constantly exposed to the risk of being sucked into and devoured by the Vacuum, like the heroine in Oshima's film. In Seminar $\mathrm{XXV}$, Lacan states that the sexual relationship is equivalent to the empty set (Lacan, 1977, the lesson of 15 November 1977). Modifying this statement slightly, let us state that the sexual relationship in its fantasmatic form is not simply equivalent to the empty set, but to the vacuum that can nullify the subject through the fatal temptation of becoming the One. While lovers wager on the possibility of infinitizing the power of the amorous truth, they also come to terms with the danger of getting bogged down in the black hole of the sexual vacuum. The real of the absolute does not allow us to say all of the absolute truths. To say them all is impossible. This is why we can finally agree to Badiou with some irony when he states that "concerning the absolute, there is, Lacan would state, nothing but an always lacunary saying" (Badiou, 2018a, pp. 499-500).

\section{Amorous labor, dialectic between Euvre and waste, and artisan of love}

Let us summarize our five points. First, the framework "Lacanian finitude vs Badiouian infinity" can be misleading. Second, for Badiou himself, the unconscious and the analytic discourse are inscribed by the dialectic between finitude and infinity. Third, Lacan allows us to recognize that the œuvre and the waste do not stand in opposition, but rather supplement each other. Fourth, for both Lacan and Badiou, love constitutes the interlacing of the non-relationship and the Two. Fifth, the Badiouian amorous absolute must stay moderate toward the real of the absolute as the fusional One and thus, cannot be conceived as separate from the Lacanian sexual relationship of the One in its fantasmatic form. What then is a term capable of epitomizing all of these points? This article argues that it is an amorous labor. For Badiou, love is a labor, because it is neither sublime nor trivial (Badiou, 2018a, p. 622). Love is a labor, because it is a procedure of constructing the immanent Two. However, a Lacanian supplementation to L'Immanence des vérités allows us to recognize that love is a labor in a more concrete and comprehensive way. Love is a labor, because it is a process affected by the unconscious as the finite/infinite knowledge and yet moves towards the untotalizable truth, because it is a work that deals with waste as the passive remainder of infinity and creates the ouvre as the active effect of infinity, because it is a practice that struggles with the limit of the sexual non-relationship and launches into the singular Two, and because it is a force that connects the void and the multiple with infinity without falling prey to the temptation posed by the sexual relationship of the One as the Vacuum. In fact, an amorous labor implies the following point experienced by every lover: all of the anguish and happiness proper to love comes from and consists of the amorous labor itself. Love contains anguish, because it requires a constant struggle with the infinite difference of the unconscious structure of each individual, and yet, it remains a happy labor because it allows us to touch upon the unprecedented infinity that can be produced by the expansion of the pure difference of the Two. For this reason, an amorous labor can become a labor of love. An amorous labor is both a stammering act that works through the sexual impasse and a limping march that constructs the faithful Two.

This idea of an amorous labor provokes a new approach to the problem of the amorous absolute and the amorous agent. Concerning the amorous absolute, it does not exclusively belong to the ouvre. For Badiou, the concept of the index (index) serves as a criterion that distinguishes between the œuvre and the waste. It is the index that saves the œuvre from being stuck onto finitude, makes the œuvre irreducible to the archive, and leads the œuvre into touching upon the absolute (Badiou, 2018a, pp. 521-527). However, as discussed above, the distinction between the œuvre and the waste can be blurred so that the amorous absolute does not exclusively belong to the realm of the œuvre. The amorous absolute in its radicality cannot be merely supported by the operation of the index; rather, it lies in something that is not directly articulated by, but can be drawn from, Badiou's discussion; this is the dialectic between the ouvre and the waste, the consequence of which is an amorous labor. Badiou argues for the creation of the ouvre through the dialectic between finitude and infinity. Love, however, goes so far as to affirm the practice of labor through the dialectic between œuvre and waste, the space of which can be conceived of as the interstitial zone of the superabsolute. While the Badiouian amorous œuvre is indexed by the absolute, love ultimately remains irreducible to and untamable by the absolute. Just as the theory of large cardinals shows that a super-compact cardinal can subsume a compact cardinal, due to its reflexivity, love opens up the zone of the super-absolute beyond the truths indexed by the absolute, due to its protean and undecidable character. Let us add the observation that, if a supercompact cardinal relativizes and subsumes a compact cardinal due to its superior degree in the kingdom of infinity, the amorous super-absolute embraces the amorous absolute and lets it remain absolute. 
In love, what is at stake is not simply that the absolute is with us all along (Badiou with Hegel), but that the lover makes him/ herself committed to a unique labor. This labor actually fits well into the etymology of absolute (absolutus). Absoluteness means being freed. While biochemical mechanisms, conjugal obligations, romantic codes, and sociopolitical ideologies signify that love is different from freedom, it is the amorous labor that evokes and proves that the lover is radically freed. A lover, however, is freed in an enigmatic way, without being able to identify or discern from what he or she is freed. A lover is freed without being freed from anything, because a lover is committed to a strange labor, from which one can neither be freed (labor constitutes love itself) nor bound to (while there are conjugal obligations, nothing essentially binds us to the amorous labor). A lover is not merely indexed by the absolute truth, but is so absolutely freed that he/ she cannot be contained or restricted by the absolute. What kind of an agent, then, is a lover? In Seminar IX, Lacan specifies that there is no such thing as the subject of love, but rather only the victim of love (Lacan, 1961, the lesson of 21 February 1962). This is because love constitutes a wound caused by the Vacuum of the sexual relationship. For Badiou's part, he articulates the subject of love, which turns the sexuality of the human animal into the material of the trans-human truth. This occurs because love constitutes a singular infinity that is heterogeneous to the finitude of the sexual. However, the amorous super-absolute calls for neither the victim of love nor the subject of love, but rather the artisan of love. Only the artisan of love knows how to devote him/ herself to the masterpiece (chef d'œuvre), while finding a way to recycle the misfired and fragmentary waste. And this artisan's elaborate workmanship does not appear only rarely in a fine museum, but frequently in our daily lives; yet, it is never totally manifest and transparent, for the amorous labor is both an intimate phenomenon and an opaque mystery.

\section{Concluding remarks: love and the interlacing of Lacan and Badiou}

The common implication of the amorous labor, the dialectic between the œuvre and the waste, and the artisan of love is the need to articulate the interlacing of Lacan and Badiou in our practice and thinking about love. While Badiou's philosophical project focuses on the critique of finitude and the affirmation of infinity, this article argues that one must return to the experience of the artisan of love from the perspective of the interlacing of Lacan and Badiou, and not simply from an empiricist or phenomenological perspective. Let us recall Fichte's description of love as "a desire for something altogether unknown, the existence of which is disclosed solely by the need of it, by a discomfort, and by a void that is in search of whatever will fill it, but that remains unaware of whence fulfillment may come" (Rougemont, 1983, p. 220). The love invoked here can be called "Bacanian," namely, Lacanian/Badiouian. It is Badiouian, in the sense that it is nonobjective movement heading toward infinity. At the same time, it is Lacanian, in the sense that it is related to desire and disclosed by discomfort and void. If this Bacanian approach to love seems too idealist, it is possible to conceive of a more sensible Bacanian figure of love.

-upper lack, with the punt, bathed off the bank, then pushed out into the stream and drifted. She lay stretched out on the floorboards with her hands under her head and her eyes closed. Sun blazing down, bit of a breeze, water nice and lively. I noticed a scratch on her thigh and asked her how she came by it. Picking gooseberries, she said. I said again I thought it was hopeless and no good going on and she agreed, without opening her eyes. [Pause.] I asked her to look at me and after a few moments-[pause]-after a few moments she did, but the eyes just slits, because of the glare. I bent over her to get them in the shadows and they opened. [Pause. Low.] Let me in. [Pause.] We drifted in among the flags and stuck. The way they went down, sighing, before the stem! [Pause.] I lay down across her with my face in her breasts and my hand on her. We lay there without moving. But under us all moved, and moved us, gently, up and down, and from side to side (Beckett, 1984, p. 61).

This passage narrates the scene of love that Krapp encountered again, while listening to the tape recording of his life episodes. Badiou proposes two different readings of this passage. According to one reading, what is at stake is the immanence of the Other inscribed in the subject's memory and the possibility of awakening (Badiou, 2003a, pp. 70-71). Despite Krapp's old age, the trace of the Other still intrudes on his isolation, and evokes the evental possibility of the other life that differs from the present lonely life. According to the alternative reading, the passage describes "the multiple of the absolute moment, the one in which love, even when in the statement of its end, suggests the infinite of the sensible" (Badiou, 2008, p. 278). At the very moment that lovers agree on the idea that their love is hopeless, lovers lay there, unmoving, but are moved by all that moves under them. As a literary reconfiguration of the Aristotelian unmoved mover or the Badiouian substance $\mathrm{V}$, the passage shows lovers engaged in a movement without movement. Even at its hopeless point of crisis and limit, love allows for a paradoxical spatio-temporality, in which lovers are radically freed like a gentle stream.

For our part, it is important to note that Beckett presents the Bacanian figure of love, namely, love in its structural limit and its absolute trace. We can illustrate this point by contextualizing Krapp's last speech within the structure of the play. Krapp finally states: "Perhaps my best years are gone. When there was a chance of happiness. But I wouldn't want them back. Not with the fire in me now. No, I wouldn't want them back" (Beckett, 1984, p. 63). One may claim that, while Krapp is now indulged in his perverse practice of listening to his recordings, the amorous scene in question may belong to one of Krapp's best years, when he had a chance of happiness. A brief re-encounter with this scene, however, is so strong that it infiltrates Krapp's solitude, kindling fire in him. This absolute trace of love, which eventally causes the resurrection of the amorous fire, serves as the Spinozian-Badiouian index of truth. Truth is the index of both itself and the false (verum index sui et falsi). It is not the case that Krapp was previously in love and now exists in solitude. Rather, Krapp's past and present are marked indelibly by the amorous scene and can be re-marked by it in an unpredictable way. Therefore, love in its absolute trace is already enough for him, so "he would not want them back." Meanwhile, let us note that, despite his random and impatient manipulation, Krapp repeatedly runs into the recording of this amorous scene over the course of the play. The scene thus amounts to the Lacanian real, as that which always returns to the same place. Krapp will have remained irresistibly attached to and haunted by the amorous scene in a symptomatic way. Here, love is discovered and re-discovered only through its loss. As in the Freudian-Lacanian aim of drive, he will have circumnavigated the hole of the de-naturalized drive beyond the satisfaction of biological need, extracting his jouissance from the amorous mis-encounter without knowing what he is involved in. As Mladen Dolar argues against Badiou, "who sees in the death drive merely a morbid preoccupation with death, [if] death drive is a pure thrust of persistence which cannot be annihilated," the amorous scene evokes death drive in its excessive and demonic immortality (Dolar, 2005, p. 159). The amorous scene 
thus constitutes a structural limit to Krapp's subjectivity. This time, fully exhausted by the demonic repetition of the loss of love, "he would not want them back."

Let us provide a formulation of love's intrinsic ambivalence at a more general level. In Seminar XXII, Lacan declares: "And that is why love is precious, eh!, rarely realized, as everyone knows, only lasting for a time and all the same made up of the fact that it is essentially this breaking down of the wall where one can only give yourself a bump on the forehead, in short, that is at stake" (Lacan, 1974, the lesson of 21 January 1975). For Lacan, the preciousness, rarity, and transience of love are correlative with the fact that love is an attempt to breach its own impasse, which never authorizes an easy way through. Any attempt to surmount the lovewall (amur) results in an insurmountable bump. Here, love appears as an impassable impasse. For Badiou, what matters is not breaking down the wall (fracturer le mur), but jumping over the wall (faire le mur) of relativism, nihilism, and skepticism. To create the œuvre of love, one should not rely on existing norms to bypass the wall, nor tolerate being imprisoned behind the wall. Love can and must touch upon its proper infinity beyond the power of finitude. Of course, this love is not devoid of a risk or obstacle. But it contains a sort of surplus, undisturbed by and invulnerable to the impasse. This surplus is borne of turning the stumbling block of the sexual into a stepping-stone of the amorous. Love preserves its index of the absolute, despite a bump on the forehead. Here, love appears as an impassible pass. We thus reach the following formulation, from the perspective of the interlacing of Lacan and Badiou: Love resides between an impassable impasse and an impassible pass.

To conclude, L'Immanence des vérités shows that love is an itinerary of the absolute that passes through the dialectic between finitude and infinity. As Badiou is not only supplemented by but also interlaced with Lacan, however, we have been inspired to move beyond love as theorized in L'Immanence des vérités. Here, it is possible to witness love glimmering at the gap between the ouvre and the waste, the Two and the nonrelationship, the truth and the hole, the absolute and the Vacuum. There is no eros of integration, but rather an errancy of interstice. In this errancy, it is possible to envision the artisan of love, who stands obliquely between the victim of love and the subject of love, enduring the amorous labor, holding dear the misfired waste of love, and constructing the infinite subjective world. Finally, every lover would hear this artisan, who sometimes tires, but never gives up on the laborious work, voice wishfully, "Let love become an integral absolution for the superabsolute interstice."

\section{Data availability}

All data generated or analyzed during this study are included in this published article.

Received: 2 September 2020; Accepted: 13 July 2021;

Published online: 27 July 2021

\section{Notes}

1 Regarding the necessity and significance of this supplementary approach, see e.g. Bryant (2007).

2 For a detailed explanation of this framework and its discursive context, see Price (2015, pp. 162-164).

3 This clearly shows where Badiou and Lacan diverge. While love is separated from hatred for Badiou, love is inseparable from hatred for Lacan.

4 One might state that while Badiou focuses on the properly amorous process, Lacan

focuses on the analytic process. However, Badiouian amorous process and Lacanian analytic process are not purely detached. As Badiou notes, it is Freudo-Lacanian psychoanalysis that reinvents love after Plato's declaration of the significance of love for philosophy. Not just transference but also the analytic process provides a new material for the philosophical approach to love. Let us imagine an amorous situation in which two individuals whose respective unconscious structure is founded on certain signifiers, which hamper the construction of the scene of the two. Here, unlike Badiou who simply relies on evental encounter and subjective fidelity, Lacanian clinic soberly considers that unless the current signifying chains of two individuals are restructured (which is the aim of the analytic process), the amorous process is doomed to failure. Moreover, what Lacanian clinic calls the body-event as the emergence of the real during the analytic process is directly relevant for the elaboration of the power of the two. In the amorous process, lovers necessarily should be able to work through various kinds of body-events (impotence, frigidity, anxiety, jouissance, psychosomatic symptom), which constitutes both crisis and opportunity for the production of amorous truth. In this respect, psychoanalysis supplements philosophical idea of love in asymmetrical way. As Badiou notes, philosophy and psychoanalysis are nondialectically compossible due to love (Badiou, 2008, p. 246).

\section{References}

Badiou A (2003a). Tireless Desire. In: On Beckett. Alberto Toscano A, Power N (eds) Clinamen, Manchester

Badiou A (2004) Some replies to a demanding friend (trans: Toscano A). In: Think again: Alain Badiou and the future ofphilosophy. Hallward P (ed) Continuum, London

Badiou A (2008) Conditions (trans: Corcoran S). Continuum, New York

Badiou A (2009b) Theory of the subject (trans: Bosteels B). Continuum, New York Badiou A (2012) In praise of love (trans: Bush P). Serpent's Tail, London

Badiou A (2014). Toward a new thinking of the absolute. Crisis Critique Special Issue: $11-21$

Badiou A (2018a) L'Immanence des vérités. Fayard, Paris

Badiou A (2018b) Citéphilo conference. https://www.youtube.com/watch?v=6sFK0ThZMM

Badiou A (2018c) Lacan: anti-philosophy 3. Columbia University Press, New York Beckett S (1984) Krapp's last tape. In: Samuel Beckett: The collected shorter plays. Gontarski S. E. (ed) Grove Press, New York

Bryant L (2007) Symptomal knots and evental ruptures: Žižek, Badiou and discerning the indiscernible. Int J Žižek Stud 1(2):n.p

Dolar M (2005) Nothing has changed. Filozofski vestnik, vol 2. pp. 147-160

Lacan J (1961). The seminar of Jacques Lacan book IX: Identification, 1961-1962. Unpublished translation by Cormac Gallagher

Lacan J (1967) The seminar of Jacques Lacan Book XV: the psychoanalytic act, 1967-1968. Unpublished translation by Cormac Gallagher

Lacan J (1973) The seminar of Jacques Lacan book XXI: Les non-Dupes Errent, 1973-1974. Unpublished translation by Cormac Gallagher

Lacan J (1974) The seminar of Jacques Lacan book XXII: RSI, 1974-1975 Unpublished translation by Cormac Gallagher

Lacan J (1977) The seminar of Jacques Lacan book XXV: the moment to conclude, 1977-1978. Unpublished translation by Cormac Gallagher

Lacan J (1978) Le plaisir et la règle fondamentale: Intervention à la suite de l'exposé d'André Albert. Lett de l'École Freud 24:22-24

Lacan J (1998) The seminar of Jacques Lacan Book XX: on feminine sexuality, the limits of love and knowledge, 1972-1973 (trans: Fink B). W.W.Norton \& Co, New York

Lacan J (2001) Postface au Séminaire XI. In: Autres écrits. Miller J-A (ed) Éditions du Seuil, Paris

Lacan J (2006a) L'événement Freud. In: Le Séminaire XVI: D’un autre à l'Autre, 1968-1969. Miller J-A (ed) Éditions du Seuil, Paris

Lacan J (2006b) Écrits: the first complete edition in English (trans: Fink B). W.W Norton \& Co, New York

Lacan J (2017) The seminar of Jacques Lacan Book XXIII: the Sinthome, 1975-1976 (trans: Price A). Polity, Cambridge

Lacan J (2019) The third. In: The Lacanian review 7: get real. Brousse M-H (ed) New Lacanian School, Paris

Lachaud D (1995) L'enfer du devoir: Le discours de l'obsessionnel. Denoël, Paris

Leader D (2008) The new black: mourning, melancholia and depression. Penguin, New York

Price AR (2015) "I START OFF FROM THE LIMIT," on the first lesson of Seminar XX, Encore. Lacunae 11:131-164

de Rougemont D (1983) Love in the western world (trans: Belgion M. Princeton University Press, Princeton

Vinciguerra R-P (2014) Femmes lacaniennes. Éditions Michèle, Paris

\section{Acknowledgements}

This work was supported by the Ministry of Education of the Republic of Korea and the National Research Foundation of Korea (NRF-2019S1A5B5A01041916). 


\section{Competing interests}

The author declares no competing interests.

\section{Additional information}

Correspondence and requests for materials should be addressed to P.Y.

Reprints and permission information is available at http://www.nature.com/reprints

Publisher's note Springer Nature remains neutral with regard to jurisdictional claims in published maps and institutional affiliations. (c) Open Access This article is licensed under a Creative Commons Attribution 4.0 International License, which permits use, sharing, adaptation, distribution and reproduction in any medium or format, as long as you give appropriate credit to the original author(s) and the source, provide a link to the Creative Commons license, and indicate if changes were made. The images or other third party material in this article are included in the article's Creative Commons license, unless indicated otherwise in a credit line to the material. If material is not included in the article's Creative Commons license and your intended use is not permitted by statutory regulation or exceeds the permitted use, you will need to obtain permission directly from the copyright holder. To view a copy of this license, visit http://creativecommons.org/licenses/by/4.0/.

(C) The Author(s) 2021 